\title{
The Burden of Penile Cancer in Bali Compared to Other Provinces in Indonesia
}

\author{
Desak Putu Oki Lestari ${ }^{1 *}$ D, I Nyoman Putu Riasa ${ }^{2}$, Putu Kania Iswari Niramayah ${ }^{3}$, Ni Wayan Armerinayanti ${ }^{1}$, Putu Nita \\ Cahyawati $^{4}$, Kartika Sari ${ }^{5}$, Irianiwati Widodo ${ }^{6}$, Rika Mubarika Haryana ${ }^{7}$

\begin{abstract}
${ }^{1}$ Department of Anatomical Pathology, Faculty of Medicine and Health Sciences, Warmadewa University, Bali, Indonesia; ${ }^{2}$ Department of Plastic Surgery, Faculty of Medicine, Universitas Udayana, Bali, Indonesia; ${ }^{3}$ Faculty of Medicine, Public Health, and Nursing, Universitas Gadjah Mada, Yogyakarta, Indonesia; ${ }^{4}$ Department of Pharmacology and Pharmacy, Faculty of Medicine and Health Sciences, Warmadewa University, Bali, Indonesia; ${ }^{5}$ Department of Biomolecular, Faculty of Medicine and Health Sciences, Warmadewa University, Bali, Indonesia; ${ }^{6}$ Department of Anatomical Pathology, Faculty of Medicine, Public Health, and Nursing, Universitas Gadjah Mada, Yogyakarta, Indonesia; ${ }^{7}$ Department of Histology and Cellular Biology, Faculty of Medicine, Public Health, and Nursing, Universitas Gadjah Mada, Yogyakarta, Indonesia
\end{abstract}

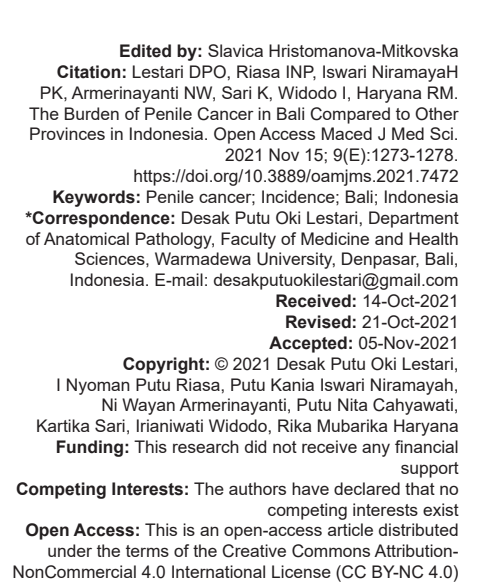

Introduction

Penile cancer is classified into rare cancer in the world with a prevalence of $0.3-1 / 100,000$ men in industrial countries and in the area that does routine circumcision [1], [2], [3]. However, there were variations of penile cancer incidence in various populations in the world. The highest incidence rate was found with an age-standardized incidence rate (ASR) of 6-7/100,000 men found in Canada, Brazil, and Romani [2], [4], [5]. The incidence was found to be higher in regions with the lower income [7]. Data from Globocan 2018 showed 34,475 new cases of penile cancer in the world and 15,138 mortality associated with penile cancer [1]. The mortality rate of penile cancer in countries with a high incidence of penile cancer, such as Brazil, was found 0.3-0.5/100,000 men [6]. Penile cancer was also rarely found in most parts of Indonesia except Bali Province, where can find high numbers. It is also ranked as the most common cancer among the male population in Bali, followed by prostate cancer [8].

The cause and risk factors for penile cancer are unclear. It has been associated with multiple factors, which includes: a history of no circumcision, chronic inflammation such as balanoposthitis, phimosis, and balanitis xerotica obliterans, poor hygiene, low socioeconomic status, history of multiple sex partners, ultraviolet phototherapy, HIV and HPV infections, obesity, smoking, as well as Bowen's disease, and zoophilia [9], [10], [11], [12]. Studies conducted in Brazil also showed that men who work as farmers have a higher risk of developing penile cancer [13]. Most patients presented with pruritus and other symptoms such as ulcers, nodules, or tumors with secrete [4]. Another study conducted in Sanglah General Hospital Denpasar in Bali showed that several risk factors are associated with penile cancer, including non-circumcision (100\%), history of phimosis $(87 \%)$, and urinary tract infections (72\%) [14]. 


\section{Materials and Methods}

The total sample in this study is 1032 new cases of penile cancer from 11 provinces in Indonesia which were collected manually from the Anatomical Pathology Cancer Registry from 2004 to 2013. Thirteen registries were used. We excluded 20 cases due to unknown age data. A total of 460 cases of the total penile cancer cases came from Bali. Crude rate incidence $(\mathrm{CRI})$ and $A S R$ are calculated based on the number of new penile cancer cases per 100,000 male population in a given province over 10 years. $\mathrm{CRI}$ trends were calculated using a linear regression test. Indonesian population standard was used to calculate ASR.

Medical Research Ethics Committee Udayana University, Sanglah General Hospital Denpasar approved this study with ethics approval number: 1559/UN 14.2.2/PD/KEP/2018.

\section{Results}

\section{Age standardized incidence rates and age specific incidence rate}

The age standardized incidence rates for 10 years period was found to be highest in Bali compared to other Indonesian Provinces. ASR for penile cancer in Bali was 2.1/100,000 males, while in other provinces it was $<1 / 100,000$ males (Figure 1).

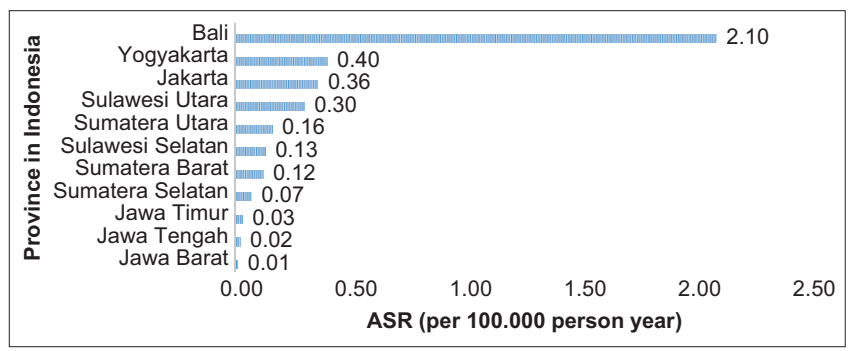

Figure 1: Bar chart of province-Age Standardized Incidence Rate (ASR) in 11 Indonesian provinces in the 2004-2013 period. Rates are shown in descending order of Indonesia ASR for penile cancer

Penile cancer incidence was affirmed to be higher in older age groups. The highest age-specific incidence rate (AR) in Bali, South Sumatera, and South Sulawesi is in the age group of $65-76$ years old. The peak incidence in Yogyakarta, West Sumatera, Jakarta, and North Sulawesi was found in an older age group of $>75$ years old. Meanwhile, the highest AR in North Sumatera and West Sumatera was found in younger age groups, with North Sumatera being 45-54 years old, and West Sumatera 55-64 years old. The incidence of penile cancer increases with age in Bali male patients, with a peak AR of $12.9 / 100,000$ men in the age group of 65-75 years, then decreased slightly in the $>75$ years of age group with AR 11.9/100,000 men. In general, penile cancer is rarely found in the younger age group. However, this study discovered that the AR of the 25-34 years old male group in Bali to be relatively high, which is $0.9 / 100,000$ men (Table 1 ).

Table 2: CRI of penile cancer in Indonesia

\begin{tabular}{lllll}
\hline No & Year & Cases & Male population & CRI \\
\hline 1 & 2004 & 78 & 108418600 & 0.07 \\
2 & 2005 & 99 & 109769300 & 0.09 \\
3 & 2006 & 117 & 111008800 & 0.11 \\
4 & 2007 & 149 & 112262300 & 0.13 \\
5 & 2008 & 122 & 113530000 & 0.11 \\
6 & 2009 & 120 & 114811900 & 0.10 \\
7 & 2010 & 118 & 116108300 & 0.10 \\
8 & 2011 & 94 & 120388300 & 0.08 \\
9 & 2012 & 101 & 122094200 & 0.08 \\
10 & 2013 & 145 & 123782100 & 0.12 \\
& Total & 1143 & 1152173800 & 0.10 \\
\hline
\end{tabular}

\section{CRI}

The average CRI for 10 years period in Indonesia is $0.1 / 100.000$ males (Table 2). In some provinces, such as Bali, Yogyakarta, and East Java, $\mathrm{CRI}$ was higher in comparison to ASR. CRI for 10 years period was observed to be highest in Bali compared to other Indonesian provinces, with a score of 2.5/100,000 men. The second highest was found in Yogyakarta, the third in Jakarta, and the fourth in Sulawesi Utara, and the lowest was in Jawa Barat (Figure 2).

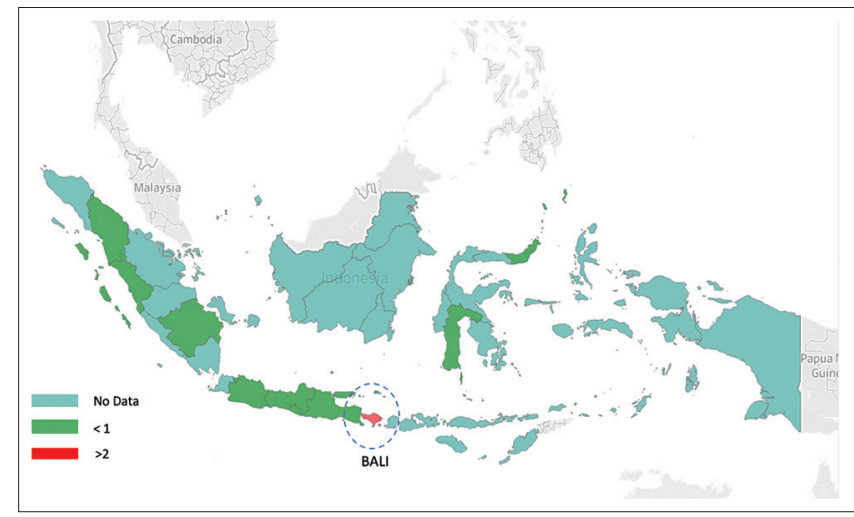

Figure 2: Geographic distribution of crude incidence rate 11 Indonesian Provinces in the 2004-2013 period

Table 1: Calculation of age specific incidence rate in 11 Indonesian provinces in the 2004-2013 period

\begin{tabular}{|c|c|c|c|c|c|c|c|c|c|c|}
\hline \multirow[t]{2}{*}{ Province } & \multirow[t]{2}{*}{ Cases } & \multirow[t]{2}{*}{ Person-year at risk } & \multicolumn{8}{|c|}{ Age specific incidence rate (per 100,0000 male) } \\
\hline & & & $<15$ & $15-24$ & $25-34$ & $35-44$ & $45-54$ & $55-64$ & $65-75$ & $>75$ \\
\hline Sumatera Utara & 90 & 64986500 & 0 & 0 & 0.1 & 0.3 & 0.6 & 0.3 & 0.4 & 0.2 \\
\hline Sumatra Barat & 29 & 25490500 & 0 & 0 & 0.1 & 0.1 & 0.3 & 0.5 & 0.1 & 0.6 \\
\hline Sumatera Selatan & 21 & 36317500 & 0 & 0 & 0 & 0.1 & 0,1 & 0,2 & 0.8 & 0.5 \\
\hline Jakarta & 155 & 47324000 & 0 & 0.1 & 0.2 & 0.4 & 1 & 0.9 & 2.1 & 2.7 \\
\hline Jawa Barat & 13 & 209682500 & 0 & 0 & 0 & 0 & 0 & 0 & 0 & 0 \\
\hline Jawa Tengah & 29 & 163929500 & 0 & 0 & 0 & 0 & 0.1 & 0 & 0 & 0 \\
\hline Jawa Timur & 70 & 185251500 & 0 & 0 & 0 & 0 & 0.1 & 0.2 & 0.1 & 0.1 \\
\hline Yogyakarta & 85 & 16736000 & 0.1 & 0 & 0 & 0.5 & 1.2 & 1.7 & 1.3 & 2 \\
\hline Bali & 449 & 18301500 & 0 & 0.1 & 0.9 & 2.1 & 4.7 & 8.7 & 12.9 & 11.9 \\
\hline Sulawesi Utara & 46 & 16470000 & 0 & 0 & 0.1 & 0.2 & 0,6 & 0.9 & 1.5 & 2.2 \\
\hline Sulawesi Selatan & 49 & 41156000 & 0 & 0 & 0.1 & 0.2 & 0.4 & 0.3 & 0.7 & 0.4 \\
\hline
\end{tabular}




\section{Crude incidence rate trend in 2004-2013 Period in Indonesia}

CRI of penile cancer in Bali trended upward, beginning in 2004 and reached the first peak at 2006 with the score of $3.99 / 100,000$ men, followed by a downward trend and reached its lowest point in 2001 with 1.36/100,000 men. From 2011, it showed a defined upward trend reaching 3.38/100,000 men in 2013. The overall 10-year trend showed no significant change with an R-square result of $0.02(p=0.64)$ (Figure 3$)$.

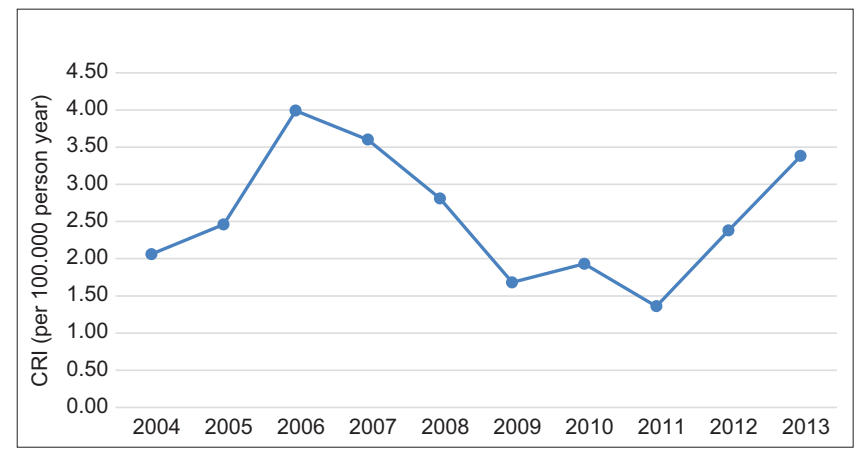

Figure 3: Line graph depicting year-on-year CRI of Bali Province in 2004-2013 period

Yogyakarta placed second in CRI rank with an overall 10-year CRI of 0.5 per 100,000 men. Incidence of penile cancer reached its lowest point in 2005-2006 period followed by an increasing trend peaking at 1.2/100,000 men in 2007. Afterward, it showed a downward trend followed by another climb reaching its second peak at 2009 with 0.8/100,000 men. Incidence then declined from 2009 to 2012 with a slight increase ending with 0.5/100,000 men in 2013 (Figure 4).

In third place was Jakarta, with an overall 10-year CRI of $0.33 / 100,000$ men. The first peak incidence was reached in 2008 with a $\mathrm{CRI}$ of $0.41 / 100,000$ men and the second peak was in 2011 with $0.43 / 100,000$ men. From 2008, the incidence of penile cancer showed a general declining trend reaching a CRI of 0.26/100,000 men in 2013 (Figure 5).

Although Sulawesi Utara was found with the fourth-highest CRI with an overall figure of $0.3 / 100,000$ men, the figures showed a general downward trend throughout the observation period with the highest CRI observed in 2004 with 0.66/100,000 men. Regression analysis showed a declining trend of penile cancer

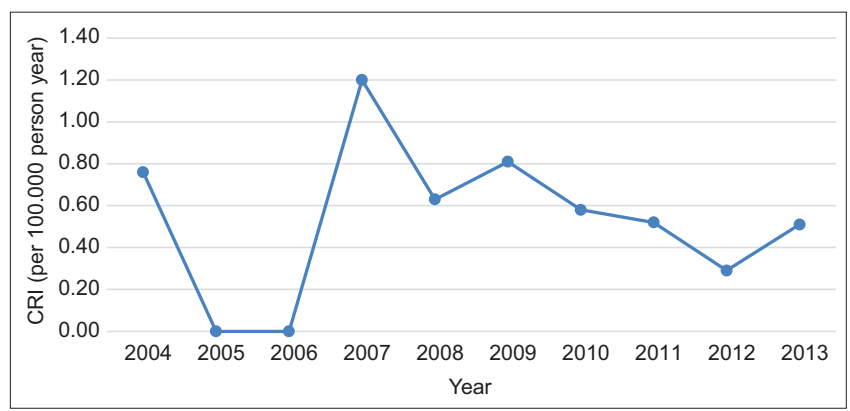

Figure 4: Line graph depicting year-on-year of Yogyakarta Special Region in 2004-2013 period

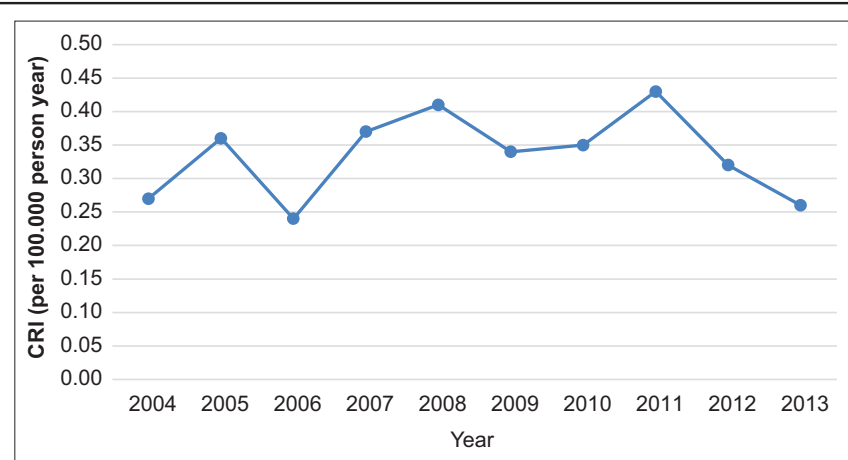

Figure 5: Line graph depicting year-on-year CRI of Jakarta Special Capital Region in 2004-2013 period

incidence, with an R-squared value of 0.6 and $p=0.01$ (Figure 6).

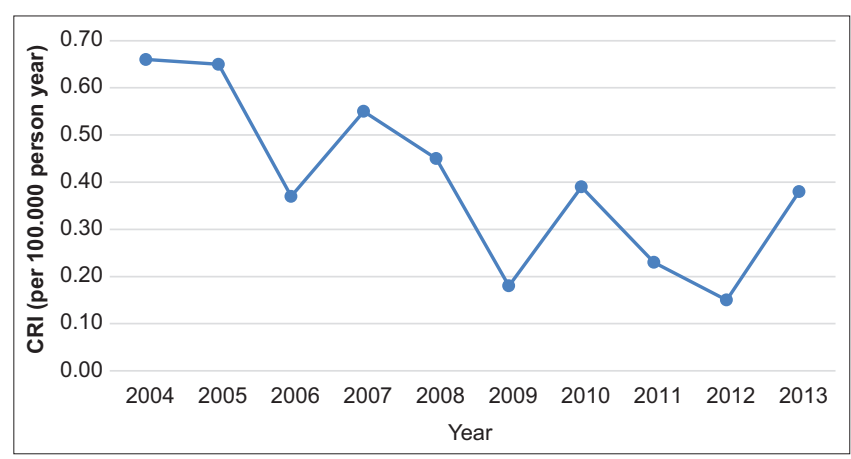

Figure 6: Line graph depicting year-on-year CRI of Sulawesi Utara Province in 2004-2013 period

Average CRI of penile cancer in Sumatra Utara was $0.14 / 100,000$ men from 2004 to 2013 . It peaked in 2013 with $0.28 / 100,000$ men (Figure 7).

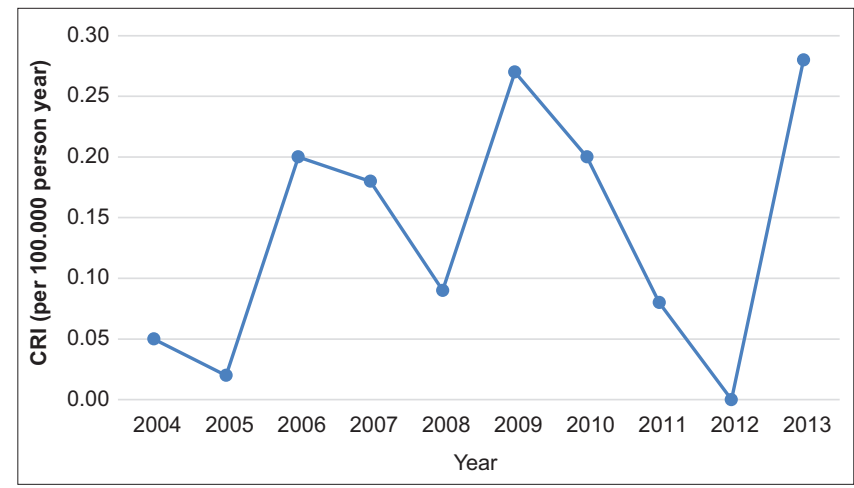

Figure 7: Line graph depicting year-on-year CRI of Sumatera Utara Province in 2004-2013 period

Development of penile cancer incidence in Sulawesi Selatan during the 10-year observation period showed an overall CRI of $0.12 / 100,000$ men. Year-by-year observation showed the incidence rate increased and reached its peak in 2010 with a score of 0.27/100,000 men (Figure 8).

The crude incidence rate for ten years in Sumatera Barat was $0.11 / 100,000$ men. It peaked in 2005 with $0.45 / 100,000$ followed by a downward trend reaching its lowest point in 2013 (Figure 9). 


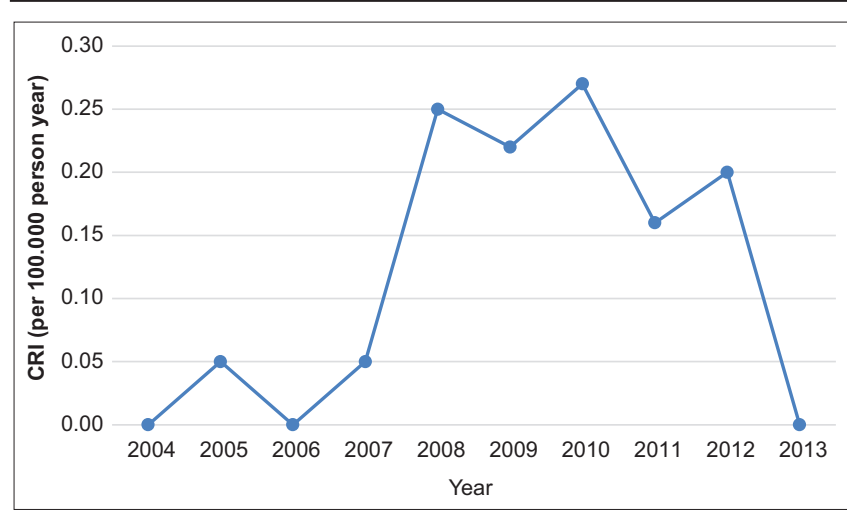

Figure 8: Line graph depicting year-on-year CRI of Sulawesi Selatan Province in 2004-2013 period

CRI from 2004 to 2013 in Sumatera Selatan was $0.06 / 100,000$ men. Development of these figures showed three peaks in 2005 with $0.19 / 100,000$ men, in 2008 with $0.08 / 100,000$ men, and 2011 with $0.06 / 100,000$ men (Figure 10).

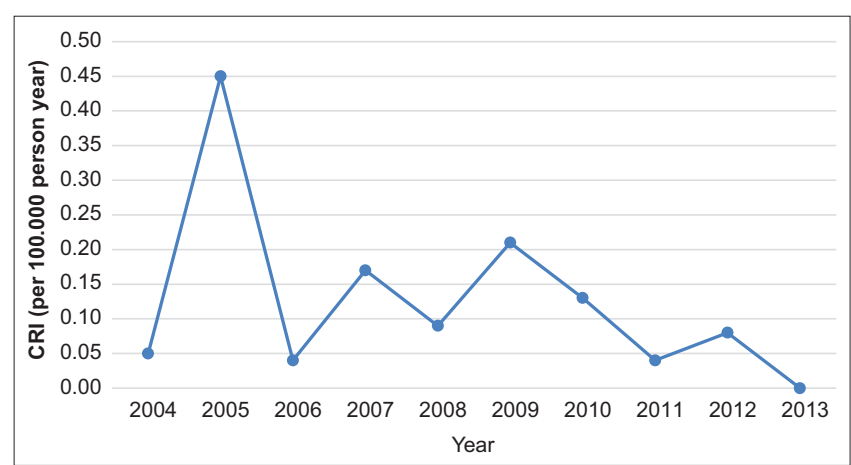

Figure 9: Line graph depicting year-on-year CRI of Sumatera Barat Province in 2004-2013

The overall crude incidence rate for penile cancer in Jawa Timur from 2004 to 2013 was $0.04 / 100,000$ men. In the 10 years, the CRI increased, reaching its highest value in 2008 and 2010, followed by a descending trend until 2013 (Figure 11).

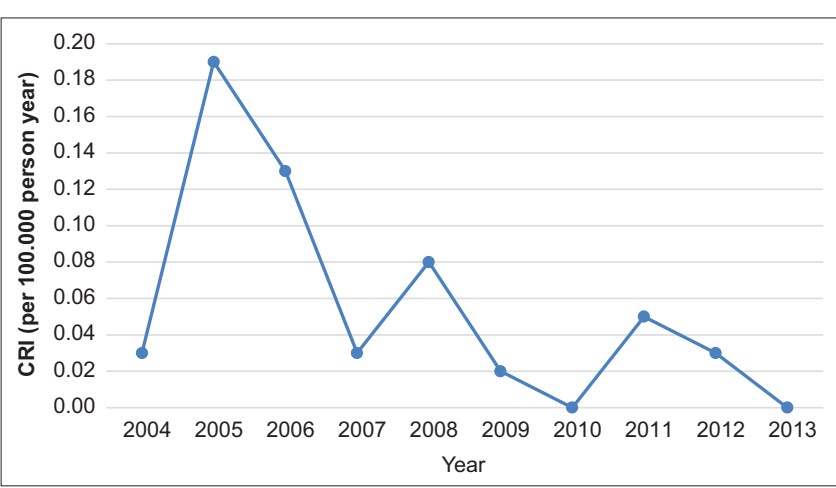

Figure 10: Line graph depicting year-on-year CRI of Sumatera Selatan Province in 2004-2013

The crude incidence rate of penile cancer in Jawa Tengah from 2004 to 2013 was $0.02 / 100,000$ person-year. There were two peak periods in 2009 and 2013 with an incidence of $0.05 / 100,000$ men (Figure 12).

$\mathrm{CRI}$ for Jawa Barat was the lowest compared to others, with $0.01 / 100,000$ per year. However, the

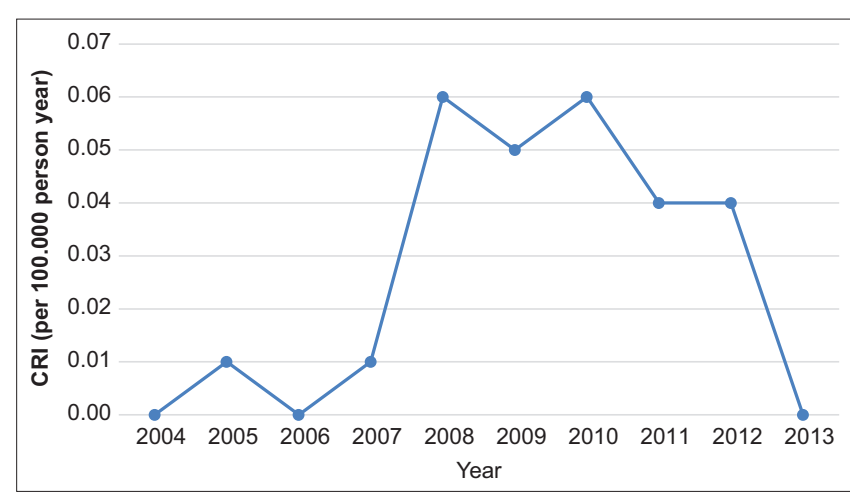

Figure 11: Line graph depicting year-on-year CRI of Jawa Timur Province in 2004-2013

10-year observation period showed an ascending trend from 2011 to 2012 which plateaued in 2013 (Figure 13).

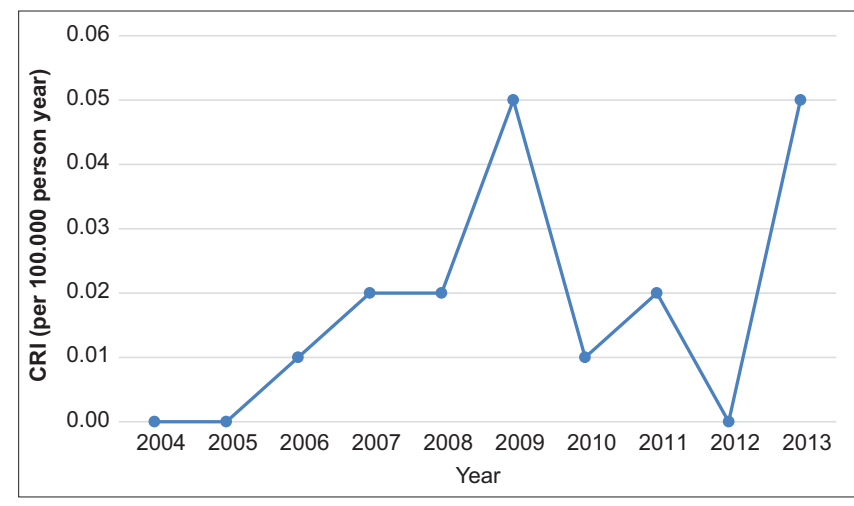

Figure 12: Line graph depicting year-on-year CRI of Jawa Tengah Province in 2004-2013

The incidence of penile cancer in Bali was far higher than in other included Indonesian provinces. The incidence showed an upward trend from 2011, with the first peak in 2006 and the second in 2013. The incidence of penile cancer outside Bali was $<1 / 100,000$ men, with a significant declining trend in Sulawesi Utara.

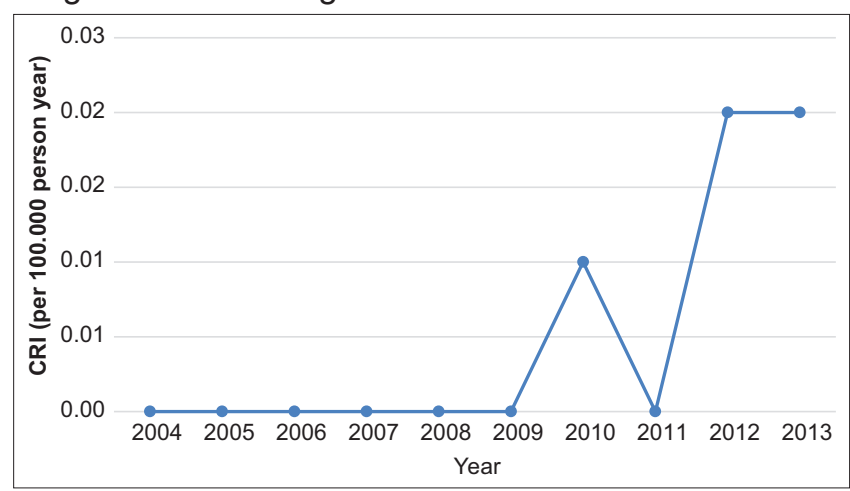

Figure 13: Line graph depicting year-on-year CRI of Jawa Barat Province in 2004-2013

\section{Discussion}

A total of 1032 new cases of penile cancer was diagnosed in 11 Indonesian provinces from 2004 to 
2013. The average of CRI penile cancer in Indonesia is minimal, which is $0.1 / 100.000$ men. Calculation incidence in several of Indonesia's provinces showed varying figures, with the lowest average ASR of $0.01 / 100,000$ men in Jawa Barat and the highest with 2.1/100,000 person-year in Bali. The incidence of penile cancer in Bali was remarkably higher compared to other provinces, five times higher to Yogyakarta and Jakarta and 210 times higher to Jawa Barat. The incidence of penile cancer in Bali is the same as that found in Sweden [15]. Data from the WHO showed ASR in regions with high penile cancer prevalence was $2-4$ per 100,000 men [16], indicating that the incidence of penile cancer in Bali is high. Penile cancer cases in several Asian countries show a higher incidence than Indonesia, such as India with an ASR 2.7/100,000 men [17], Vietnam with a score of $2.34 / 100,000$ men, and Thailand with 3.46/100,000 men [2]

There are several risk factors in the carcinogenesis of penile cancer [11], [12], [18]. A study on penile cancer in Bali showed that the risk factors included having a history of phimosis, uncircumcised, and having more than one wife. Most patients have low education and work as farmers, drivers, and traders [14]. Most Balinese people adhere to Hinduism, and uncircumcised was common in other provinces, mainly the Muslim population. The same situation is found in India, where penile cancer incidence is discovered to be higher in the non-Muslim population than in the Muslim population [17]. The profile of penile cancer patients in Brazil, which has the highest incidence of penile cancer globally, found a history of zoophilia in $60 \%$ of cases, sexually transmitted infection $55 \%$, and other risk factors such as phimosis and poor hygiene [19].

Low incidence of penile cancer in developed countries such as the United States, with an ASR of 0.81 cases $/ 100,000$ males, was suspected to be indirectly associated with the success of the HPV vaccination program for women [4]. A different condition is found in Bali, where the incidence of cervical cancer remained the second most frequent malignancy found among Balinese women, and coverage of pap smear screening remained low [20]. Moreover, HPV vaccination coverage which was still low coupled with the sub-optimal implementation of the vaccination program, may have contributed to the high incidence of penile cancer in Bali and other Indonesian provinces. The protective effect of routine neonatal circumcision can prevent phimosis-induced chronic inflammation and is effective in reducing penile cancer incidence [7], [22]. Circumcision is proven to protect against penile cancer when performed on children or adulthood [23]

Penile cancer in Indonesia can be found in older age groups, especially in the fifth to seventh decades of life, with a variation of peak incidence found between Indonesian Provinces. The AR of penile cancer in Bali was found higher for increasingly older men with peak incidence found for 65-75 years old age group, which was 12.9/100,000 men. Another study in Norway showed similar figures with peak incidence observed among men aged 70 years [24]. Penile cancer in Indonesia can be found in older age groups, especially in the fifth to seventh decades of life, with a variation of peak incidence found between Indonesian provinces. The AR of penile cancer in Bali was found higher for increasingly older men, with peak incidence found for $65-75$ years old age group which, was 12.9/100,000 men. Another study in Brazil with a high incidence of penile cancer reported $22 \%$ of people living with penile cancer younger than 45 years [19].

Calculating penile cancer incidence is critical as a fundamental study to determine how big the problem of penile cancer cases is in Indonesia, especially in Bali province. The limitation of this study is that cancer registry represents only 11 from 34 provinces in Indonesia and the limitation of demography data.

\section{Conclusion}

The overall average CRI of penile cancer in 10 years (2004-2013) in Indonesia is low, but the ASR is found high in Bali Province compared to other areas. Serious attention needs to be paid to Bali. All efforts to find risk factors for penile cancer should be made and can be used as a basis for cancer prevention strategy and further research.

\section{Author Contributor Statement}

This manuscript has been read and approved by all authors. All authors were involved in development of this manuscript.

\section{Acknowledgments}

The authors would like to convey gratitude to all anatomic pathologists incorporated in Indonesian Anatomic Pathologist Association in all anatomic pathologic laboratories which contributed to the development of cancer registration in Indonesia.

\section{References}

1. Bray F, Ferlay J, Soerjomataram I, Siegel RL, Torre LA Jemal A. Global cancer statistics 2018: GLOBOCAN estimates 
of incidence and mortality worldwide for 36 cancers in 185 countries. CA Cancer J Clin. 2018;68(6):394-424. http://doi. org/10.3322/caac.21492

PMid:30207593

2. Cardona CE, García-Perdomo HA, Cardona CE, García-Perdomo HA. Incidence of penile cancer worldwide: Systematic review and meta-analysis. Rev Panam Salud Pública. 2018;41:e117.

PMid:31384255

3. Cubilla AL, Amin MB, Ayala A, Ayala G, Chaux A, Corbishley C. Tumours of the penis, malignant epithelial tumours. In: WHO Clasification of Tumours of the Urinary System and Male Genital Organs; 2016. p. 263

4. Vieira CB, Feitoza L, Pinho J, Teixeira-Júnior A, Lages J, Calixto J, et al. Profile of patients with penile cancer in the region with the highest worldwide incidence. Sci Rep. 2020;10(1):2965 http://doi.org/10.1038/s41598-020-59831-5 PMid:32076037

5. Lagacé F, Ghazawi FM, Le M, Savin E, Zubarev A, Powell M, et al. Penile invasive squamous cell carcinoma: analysis of incidence, mortality trends, and geographic distribution in Canada. J Cutan Med Surg. 2020;24(2):124-8. http://doi. org/10.1177/1203475419888869

PMid:31722549

6. Korkes F, Rodrigues AF, Baccaglini W, Cunha FT, Slongo J, Spiess $\mathrm{P}$, et al. Penile cancer trends and economic burden in the Brazilian public health system. Einstein (São Paulo). 2020;18:eAO5577. http://doi.org/10.31744/ einstein_journal/2020AO5577

\section{PMid:33174969}

7. Hernandez BY, Barnholtz-Sloan J, German RR, Giuliano A, Goodman MT, King JB, et al. Burden of invasive squamous cell carcinoma of the penis in the United States, 1998-2003. Cancer. 2008;113(Suppl 10):2883-91. http://doi.org/10.1002/cncr.23743 PMid:18980292

8. Lestari DP, Armerinayanti NW, Lestari D, Armerinayanti N. Increasing trend of penile cancer cases in Bali compared to other regions in Indonesia. IOP Conf Ser Mater Sci Eng 2018;434:8.

9. de Cássio Zequi S, Guimarães GC, da Fonseca FP, Ferreira U, de Matheus WE, Reis LO, et al. Sex with animals (SWA): Behavioral characteristics and possible association with penile cancer. A multicenter study. J Sex Med. 2012;9(7):1860-7. http:// doi.org/10.1111/j.1743-6109.2011.02512.x

PMid:22023719

10. Kristiansen S, Bjartling C, Svensson A , Forslund O, Torbrand C Penile intraepithelial neoplasia, penile cancer precursors and human papillomavirus prevalence in symptomatic preputium: A cross-sectional study of 351 circumcised men in Sweden. BJU Int. 2021;127(4):428-34. http://doi.org/10.1111/bju.15221 PMid:32870593

11. Douglawi A. Updates on the epidemiology and risk factors for penile cancer. Transl Androl Urol 2017;6(5):785-90. http://doi. org/10.21037/tau.2017.05.19

PMid:29184774

12. Hakenberg OW, Compérat EM, Minhas S, Necchi A, Protzel
C, Watkin N. EAU guidelines on penile cancer: 2014 update. Eur Urol. 2015;67(1):142-50. https://doi.org/10.1016/j. eururo.2014.10.017 PMid:25457021

13. de Medeiros PF Jr., Silva EH, Moura KL, de Aquino YF, Weller M. Increased risk of penile cancer among men working in agriculture. Asian Pac J Cancer Prev. 2018;19(1):237-41. http:// doi.org/10.22034/APJCP.2018.19.1.237 PMid:29374407

14. Kusmawan E, Bowolaksono WR, Widiana R. The clinical features of penile cancer patients at sanglah general hospital Bali-Indonesia. Bali Med J. 2012;1(1):1-5.

15. Kirrander P. Swedish national penile cancer register: Incidence, tumour characteristics, management and survival. BJU Int. 2016;117(2):287-92. http://doi.org/10.1111/bju.12993 PMid:25395083

16. Cubilla AL. Pathology and Genetic, Tumours of the Urinary System and Male Genital Organs. Lyon: IARC Press; 2004. p. 281-90.

17. Gajalakshmi CK, Shanta V. Association between cervical and penile cancers in Madras, India. Acta Oncol (Madr) 1993;32(6):617-20. http://doi.org/10.3109/02841869309092439 PMid:8260177

18. Olesen TB, Sand FL, Rasmussen CL, Albieri V, Toft BG, Norrild B, et al. Prevalence of human papillomavirus DNA and p16INK4a in penile cancer and penile intraepithelial neoplasia: A systematic review and meta-analysis. Lancet Oncol 2019;20(1):145-58. http://doi.org/10.1016/S1470-2045(18)30682-X PMid:30573285

19. Vieira CB, Feitoza L, Pinho J, Teixeira-Júnior A, Lages J, Calixto J, et al. Profile of patients with penile cancer in the region with the highest worldwide incidence. Sci Rep. 2020;10(1):2965. http://doi.org/10.1038/s41598-020-59831-5 PMid:32076037

20. Lestari DP, Dewi SR, Armerinayanti NW. Strengthening the role of cadres and village midwives to support the cervical cancer awareness movement in Puhu Payangan village, Gianyar Bali, Indonesia. Indones J Community Engagem. 2021;7(1):41.

21. Maden C, Sherman KJ, Beckmann AM, Hislop TG, The CZ, Ashley RL, et al. History of circumcision, medical conditions, and sexual activity and risk of penile cancer. J Natl Cancer Inst. 1993;85(1):19-24. http://doi.org/10.1093/jnci/85.1.19 PMid:8380060

22. Ornellas AA, Ornellas $P$. Should routine neonatal circumcision be a police to prevent penile cancer? Opinion: Yes. Int Braz J Urol. 2017;43(1):7-9.

23. Larke NL. Male circumcision and penile cancer: A systematic review and meta-analysis. Cancer Causes Control. 2011;22(8):1097-110. http://doi.org/10.1007/s10552-011-9785-9 PMid:21695385

24. Hansen $B T$, Orumaa $M$, Lie AK, Brennhovd $B$, Nygård $M$ Trends in incidence, mortality and survival of penile squamous cell carcinoma in Norway 1956-2015. Int J Cancer. 2018;142(8):1586-93. http://doi.org/10.1002/ijc.31194

PMid:29205336 